\title{
Peningkatan Hasil Belajar Matematika Tema Perkembangan Teknologi Melalui Penerapan Model Discovery Learning Pada Siswa Kelas III
}

\author{
Arifati Isnaeni ${ }^{1}$, I Wayan Widiana ${ }^{2}$ \\ 12Jurusan Pendidikan Guru Sekolah Dasar \\ Fakultas IImu Pendidikan, Universitas Pendidikan Ganesha \\ Universitas Pendidikan Ganesha \\ Singaraja, Indonesia \\ e-mail: arifati.isnaeni@gmail.com
}

\begin{abstract}
Abstrak
Penelitian ini bertujuan untuk menganalisis peningkatan hasil belajar Matematika siswa kelas III A SD Laboratorium Undiksha semester II tahun 2018/2019 melalui model pembelajaran Discovery Learning bermediakan benda konkret. Penelitian ini merupakan Penelitian Tindakan Kelas menggunakan model spiral dari C. Kemmis dan Mc.Taggart melalui 2 siklus. Subjek penelitian yang digunakan adalah 36 siswa. Teknik pengumpulan data yang digunakan yaitu observasi dan tes. Hasil penelitian tindakan kelas menunjukkan penerapan model pembelajaran Discovery Learning dapat meningkatkan hasil belajar matematika siswa. Hal ini dibuktikan terjadinya peningkatan rata-rata dan ketuntasan hasil belajar siswa. Rata-rata hasil belajar pra siklus sebesar 57,22 meningkat menjadi 78,61 pada siklus I. Kemudian pada siklus II rata-rata hasil belajar menjadi 86,38 . Dengan KKM 60 pada pra siklus ketuntasan sebesar $44,4 \%$, pada siklus I meningkat menjadi $80,6 \%$ dan pada siklus II meningkat menjadi $91,7 \%$. Berdasarkan hal tersebut dapat disimpulkan bahwa penerapan model discovery learning meningkatkan hasil belajar matematika siswa kelas III pada tema perkembangan teknologi.
\end{abstract}

Kata Kunci: hasil belajar matematika, discovery learning, benda konkret

\begin{abstract}
This research aims at improving mathematics learning achievement using Discovery Learning with concrete object media in class III A SD Laboratorium Undiksha. The research was Classroom Action Research with designed by Kemmis and Mc. Taggart with 2 cycle. The subject of this research were 36 students. The data collection technique of this research were observations and tests. The result show that Discovery Learning can iimprove student's mathematics achievement. Aftter using Discovery Learning, the average score increased from 57,22 to 78,61 in cycle I. In cycle II, the average mathematics achievement 86,38 . With KKM 60 in pra cycle with the completeness percentage $44,4 \%$, in cycle I improve to $80,6 \%$, In cycle 2 , improve to $91,7 \%$.
\end{abstract}

Keywords: mathematics learning achievements, realistic discovery learning, and concrete object

\section{Pendahuluan}

Pendidikan merupakan usaha sadar untuk mengembangkan perilaku dan sikap seseorang dalam masyarakat. Pendidikan memiliki peran penting bagi manusia, karena dengan pendidikan manusia dapat memperoleh pengetahuan dan keterampilan serta dapat mengembangkan kemampuan, sikap dan tingkah laku. Pendidikan di Indonesia telah mengalami banyak perkembangan ke arah yang lebih baik. Begitu pula dengan kurikulum yang berlaku di Indonesia. Saat ini pendidikan di Indonesia sedang mengembangakan Kurikulum 2013. Dalam kurikulum 2013 ini peserta didik tidak lagi mempelajari masing masing mata pelajaran secara terpisah, namun pembelajaran berbasis tematik integratif. Jadi, pada tingkatan pendidikan dasar menyuguhkan proses belajar berdasarkan tema untuk kemudian di kombinasikan dengan mata pelajaran yang ada. Salah satu muatan pelajaran pada kurikulum 2013 adalah Matematika. Pada Kurikulum 2013 muatan pelajaran Matematika pada kelas rendah yaitu kelas I, II, dan III terintegrasi ke dalam tema. Sedangkan untuk kelas 
tinggi yaitu kelas IV, V, dan VI muatan pelajaran Matematika tidak terintegrasi ke dalam tema atau berdiri sendiri.

Pembelajaran Matematika sering dianggap sebagai mata pelajaran yang sulit, sehingga tidak disukai bahkan ditakuti oleh para peserta didik. Kondisi ini dikarenakan dalam pembelajarannya, peserta didik merasa sulit dalam memahami materi dan kurangnya penggunaan media pembelajaran, sehingga mengakibatkan peserta didik merasa bosan terhadap proses pembelajarannya. Akibatnya, peserta didik merasa kesulitan dalam memecahkan soal matematika yang disajikan guru. Keberhasilan dalam pembelajaran ditentukan oleh ketuntasan siswa dalam mencapai tujuan pembelajaran. Ketuntasan tersebut dapat dicapai salah satunya dengan pemilihan model pembelajaran yang tepat. Berdasarkan hasil observasi dan wawancara awal diperoleh keterangan bahwa prestasi belajar matematika masih belum optimal atau masih rendah, karena guru menggunakan model dan metode pembelajaran yang kurang variatif sehingga peserta didik cepat merasa bosan. Dari data yang diperoleh tersebut maka perlu sekali dilaksanakan kegiatan pembelajaran yang inovatif untuk meningkatkan hasil pembelajaran matematika. Untuk mengatasi permasalahan di atas, guru harus berusaha meningkatkan dan mengembangkan kualitas proses pembelajaran matematika sesuai dengan kebutuhan peserta didik. Kualitas pembelajaran yang baik akan berdampak pada konsep matematika yang bersifat abstrak, dapat dipahami oleh semua siswa dengan mudah dan lebih bermakna. Salah satu pendekatan dalam pembelajaran matematika yang berorientasi pada hal tersebut adalah dengan menerapkan pembelajaran Discovery Learning.

Bruner (dalam Sujarwo, 2011:75) discovery lerarning atau belajar penemuan adalah berusaha sendiri untuk mencari pemecahan masalah serta pengetahuan yang menyertainya, menghasilkan pengetahuan yang benar-benar bermakna. Dalam discovery learning, siswa belajar melalui berpartisipasi secara aktif dengan konsep-konsep dan prinsip-prinsip, sehingga akan memperoleh pengalaman dan melakukan eksperimen untuk menemukan prinsip-prinsip itu sendiri. Discovery learning meningkatkan penalaran dan kemampuan berpikir secara bebas, serta melatih keterampilan kognitif untuk menemukan dan memecahkan masalah. Gorman (dalam Sujarwo, 2011:76-77) discovery learning dapat dilakukan dalam dua bentuk yaitu free discovery (penemuan bebas) dan guided discovery (penemuan terbimbing). Free discovery dalam hal ini peserta didik benar-benar dilepas dalam mengidentifikasi masalah, penyelesaian masalah, dan menguji hipotesis dengan konsep-konsep dan prinsip yang sudah ada, dan berusaha menarik kesimpulan pada situasi baru. Sedangkan guided discovery pendidik berperan sebagai pembimbing peserta didik dalam belajar. Pendidik mencoba membantu peserta didik untuk memperoleh pengetahuan yang dicarinya dengan cara mengorganisasi masalah, mengumpulkan data, mengomunikasikan, memecahkan masalah, dan menyusun kembali data-data sehingga membentuk konsep baru. Pembelajaran pada jenjang sekolah dasar masih memerlukan bimbingan pendidik, baik pada proses maupun analisis, sehingga metode penemuan ini menggunakan metode penemuan terbimbing (guided discovery).

Berdasarkan latar belakang masalah tersebut, maka peneliti akan mengkaji masalah tersebut dengan melakukan penelitian dengan judul "Peningkatan Hasil Belajar Matematika Tema Perkembangan Teknologi Melalui Penerapan Model Discovery Learning Pada Siswa Kelas III".

\section{Metode}

Desain penelitian yang digunakan adalah penelitian tindakan kelas (PTK). Menurut Arikunto (2006: 2), penelitian tindakan kelas merupakan serangkaian kegiatan yang akan kembali ke asal sehingga membentuk suatu siklus. Model penelitian tindakan kelas yang digunakan dalam penelitian ini adalah model spiral yang dikembangkan oleh Kemmis dan Mc. Taggart yaitu model siklus secara berulang dan berkelanjutan. Model ini mencakup empat komponen yaitu perencanaan (planning), tindakan (action), observasi (observation) dan refleksi (reflection). 
Penelitian ini dilakukan pada semester II yaitu pada bulan Februari-Mei 2019 di SD Laboratorium Undiksha. Penelitian tindakan kelas (PTK) ini mengambil subjek siswa kelas III A dengan jumlah 36 siswa. Perencanaan penelitian diawali dengan observasi terhadap masalah dalam pembelajaran yang terjadi di SDLaboratorium Undiksha. Kegiatan dilanjutkan dengan merencanakan tindakan yang akan dilakukan. Rencana tindakan kemudian dilaksanakan berdasarkan yang sudah direncanakan, serta dilaksanakan kegiatan observasi terhadap rencana tindakan yang dilaksanakan. Diakhiri dengan adanya refleksi.

Metode pengumpulan data pada penelitian ini menggunakan metode tes. Tes adalah alat atau prosedur yang digunakan untuk mengetahui atau mengukur sesuatu dalam suasana dengan cara atau aturan-aturan yang telah ditentukan (Arikunto, 2007: 53). Tes dalam penelitian ini digunakan untuk mengetahui hasil belajar matematika siswa setelah menggunakan metode Discovery Learning. Prosedur yang digunakan dalam tes yaitu tes akhir dengan jenis tes tertulis dalam bentuk isian singkat. Tes formatif dilaksanakan pada akhir siklus I dan II.

Data yang telah terkumpul selanjutnya dilakukan analisis data. Dalam menganalisis data ini digunakan metode analisis deskriptif kuantitatif. Menurut Agung, (2014: 142) metode analisis statistik deskriptif adalah cara pengolahan data yang dilakukan dengan jalan menerapkan rumus-rumus statistik deskriptif seperti distribusi frekuensi, grafik, angka rata-rata (Mean), median (Me), dan Modus (Mo) untuk menggambarkan keadaan objek/variabel sehingga diperoleh Data kompetensi pengetahuan matematika siswa diperoleh dengan menggunakan metode tes. Skor yang diperoleh siswa dalam tes disesuaikan dengan jumlah jawaban benar siswa. Keberhasilan suatu tindakan biasanya didasarkan pada sebuah standar yang harus dipenuhi. Adapun yang menjadi indikator keberhasilan penelitian ini adalah adanya peningkatan hasil belajar matematika kelas III A SD Laboratorium Undiksha minimal $85 \%$ siswa mendapat nilai $\geq 60$, penelitian ini dikatakan berhasil jika rerata kelas hasil belajar matematika siswa kelas III A mencapai lebih dari sama dengan $85 \%$ atau pada kategori tinggi.

\section{Hasil dan Pembahasan}

Pelaksanaan siklus I merupakan pemberian perlakuan model Discovery Learning padada pembelajaran. Kegiatan pembelajaran siklus I meliputi 4 tahap yaitu tahap perencanaan tindakan, tahap implementasi tindakan, observasi/evaluasi, dan refleksi. Uraian tindakan pada siklus I adalah sebagai berikut : Tahap perencanaan tindakan pada siklus I ini dimulai dengan penyusunan perangkat pembelajaran meliputi Rencana Pelaksanaan Pembelajaran (RPP), perangkat pembelajaran dan perangkat evaluasi. RPP siklus I dirancang untuk 2 kali pertemuan dengan materi pembahasan mengenai keliling bangun datar. RPP disertai dengan perangkat pembelajaran yang terdiri dari materi, media, sumber belajar, alat dan bahan. Selain perangkat pebelajaran RPP juga disertai dengan perangkat evaluasi yang meliputi butir soal dan rubrik penilaian. Implementasi tindakan pada siklus 1 ini dilaksanakan pada tanggal 1-3 April 2019, melalui kegiatan pembelajaran yang terbagi menjadi 2 kali pertemuan dengan alokasi waktu 4 × 35 menit untuk setiap pertemuan. Evaluasi hasil belajar matematika siswa kelas III A SD Laboratorium Undiksha semester II tahun ajaran 2018/2019 dalam aspek kognitif menggunakan tes isian berjumlah 10 soal yang memuat soal keliling bangun datar.

Peneliti melakukan evaluasi proses pembelajaran dengan mengolah hasil pengamatan aktivitas siswa selama pembelajaran berlangsung. Hal tersebut bertujuan untuk mengetahui kekurangan dari pembelajaran pada siklus I. Berikut merupakan hasil refleksi dari proses pembelajaran pada siklus I. (1) Kegiatan pembelajaran matematika melalui model Discovery Learning bermediakan benda konkret merupakan sesuatu hal yang baru bagi siswa sehingga siswa tertarik dan antusias dalam melaksanakan kegiatan pembelajaran. (2) Kegiatan pembelajaran menjadi menyenangkan dan pembelajaran menjadi lebih hidup karena siswa aktif dan terlibat secara langsung dalam kegiatan pembelajaran, (3) Kegiatan pembelajaran melalui model Discovery Learning bermediakan benda konkret dapat meningkatkan motivasi siswa dan guru kelas untuk lebih beinovasi dan berkreasi. 
Selain itu pembelajaran matematika menggunakan melalui model Discovery learning bermediakan benda konkret pada siklus I memiliki kekurangan sebagai berikut. (1) Siswa belum semuanya aktif dalam kegiatan pembelajaran. Hal itu dilihat dari adanya beberapa siswa yang pasif dan tidak mau bekerja dalam kelompok. Agar tidak terjadi hal demikian sebaiknya dalam pembagian kelompok harus merata yang anggotanya mewakili seluruh bagian dalam hal kinerja akademik, jenis kelamin, dan etnis. (2) Ada beberapa siswa yang kurang paham akan cara penggunaan pita meter. Hal tersebut dikarenakan siswa kurang fokus dalam mengikuti pembelajaran.

Siswa yang nilainya mencapai KKM sebanyak 29 siswa dari 36 siswa atau sebesar $80,6 \%$, rata-rata nilai 78,61 , dan persentase rerata hasil belajar matematika pada siklus I 78 , $61 \%$. Hal tersebut menunjukkan bahwa hasil belajar belum mencapai target yang ditentukan yaitu sebesar $85 \%$. Hasil belajar siklus I siswa sudah baik namun masih terdapat beberapa siswa yang masih belum tuntas, jadi harus ditingkat lagi, hal tersebut disebabkan oleh beberapa hal yaitu (1) siswa kurang memperhatikan saat pembelajaran, (2) saat berdiskusi kelompok baik menjawab LKS maupun melakukan pengamatan, siswa terlihat sering bermainmain dan menyerahkan tugas kepada satu atau dua orang saja, (3) siswa kesulitan ketika menyelesaikan masalah keliling bangun datar, dan siswa segan bertanya apabila menemui kesulitan saat mengerjakan LKS maupun melakukan praktikum. Kendala tersebut diduga karena kurangnya motivasi siswa dalam belajar.

Pelaksanaan siklus II merupakan pemberian perlakuan model Discovery Learning bermediakan benda konkret pada pembelajaran. Kegiatan pembelajaran siklus II meliputi 4 tahap yaitu tahap perencanaan tindakan, tahap implementasi tindakan, observasi/evaluasi, dan refleksi. Uraian tindakan pada siklus II adalah (1) Tahap perencanaan tindakan pada siklus I ini dimulai dengan penyusunan perangkat pembelajaran meliputi Rencana Pelaksanaan Pembelajaran (RPP), perangkat pembelajaran dan perangkat evaluasi. RPP siklus II dirancang untuk 2 kali pertemuan dengan materi pembahasan mengenai keliling bangun datar. RPP disertai dengan perangkat pembelajaran yang terdiri dari materi, media, sumber belajar, alat dan bahan. Selain perangkat pebelajaran RPP juga disertai dengan perangkat evaluasi yang meliputi butir soal dan rubrik penilaian.

Implementasi tindakan pada siklus II ini dilaksanakan pada tanggal 8 dan 10 April 2019, melalui kegiatan pembelajaran yang terbagi menjadi 2 kali pertemuan dengan alokasi waktu 4 x 35 menit untuk setiap pertemuan. Evaluasi hasil belajar matematika siswa kelas III A SD Lab Undiksha semester II tahun ajaran 2018/2019 dalam aspek kognitif menggunakan tes isian singkat berjumlah 10 soal. Peneliti melakukan evaluasi proses pembelajaran siklus II dengan mengolah hasil pengamatan aktivitas siswa selama pembelajaran berlangsung. Hal tersebut bertujuan untuk mengetahui kekurangan dari pembelajaran pada siklus II. Berikut merupakan hasil refleksi dari proses pembelajaran pada siklus II. (1) Kegiatan pembelajaran matematika melalui model Discovery Learning bermediakan benda konkret merupakan sesuatu hal yang baru bagi siswa sehingga siswa tertarik dan antusias dalam melaksanakan kegiatan pembelajaran, (2) Kegiatan pembelajaran menjadi menyenangkan dan pembelajaran menjadi lebih hidup karena siswa aktif dan terlibat secara langsung dalam kegiatan pembelajaran, (3) Kegiatan pembelajaran model Discovery Learning bermediakan benda konkret dapat meningkatkan motivasi siswa, (4) Siswa sudah terlibat aktif dibanding pembelajaran pada siklus I karena siswa mulai terampil dalam berdiskusi, (5) Siswa sudah paham dengan cara mengitung keliling bangun datar.

Setelah dilakukan pembelajaran dengan menerapkan model pembelajaran Discovery Learning, hasil belajar matematika siswa kelas IIIA SD Laboratorium Undiksha semester II tahun ajaran 2018/ 2019 mengalami peningkatan ketuntasan hasil belajar, naiknya nilai ratarata kelas. Untuk mengetahui perbandingan rata-rata hasil belajar pra siklus, siklus I dan siklus II secara rinci disajikan pada diagram berikut ini. 


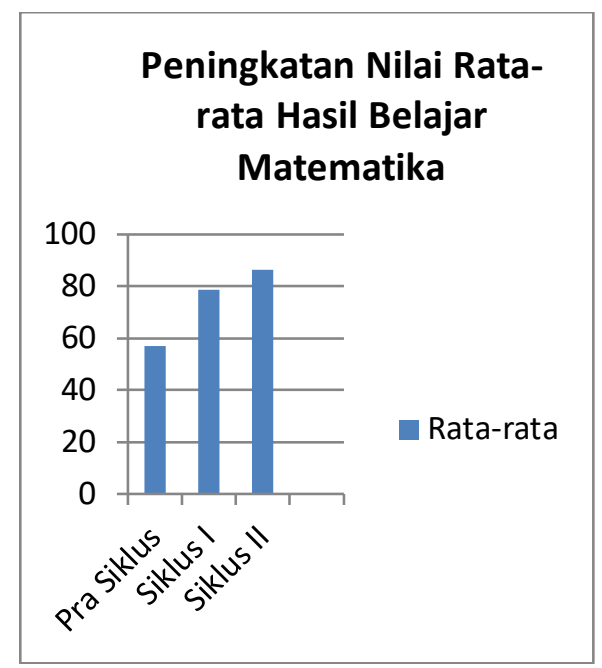

Diagram Peningkatan Nilai Rata-rata Hasil Belajar Matematika

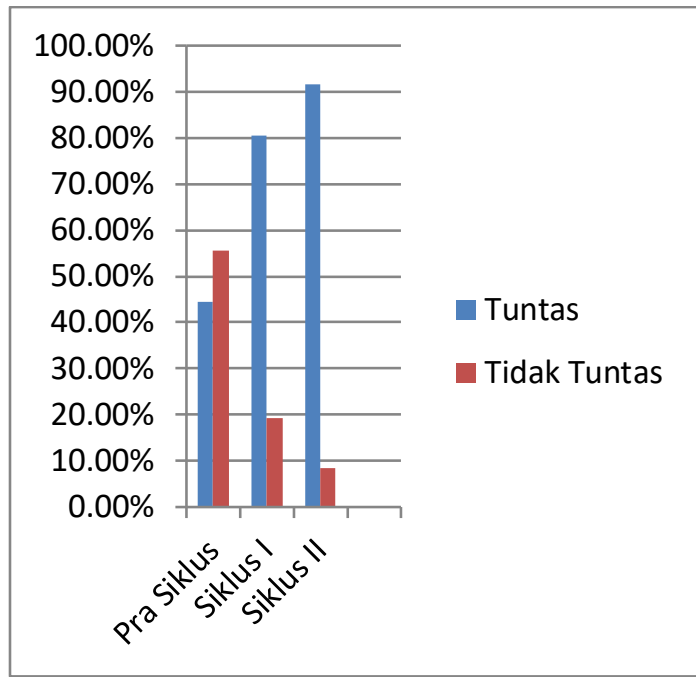

Diagram Persentase Ketuntasan Hasil Belajar Matematika

Berdasarkan diagram di atas dapat diketahui bahwa terjadi peningkatan aspek kognitif yang dapat dilihat berdasarkan hasil belajar yang diperoleh siswa. Peningkatan ini dapat dilihat dari pra siklus, siklus I, dan siklus II. Perbandingan rata-rata hasil belajar pra siklus, siklus I dan siklus II nampak rata-rata dari pra siklus sebesar 57,22 meningkat menjadi 78,61 pada siklus I. Kemudian pada siklus II rata-rata hasil belajar menjadi 86,38. Hipotesis tindakan penelitian ini terbukti bahwa model Discovery Learning bermediakan benda konkret apabila diterapkan secara efektif dan efisien, maka dapat meningkatkan hasil belajar matematika pada siswa kelas III A SD Laboratorium Undiksha semester II Tahun 2018/2019.

\section{Simpulan dan Saran}

Berdasarkan hasil penelitian yang dilakukan pada siswa kelas III A SD Laboratorium Undiksha semester II Tahun Pelajaran 2018/2019 maka dapat disimpulkan bahwa mode pembelajaran Discovery Learning bermediakan benda konkret dapat meningkatkan hasil belajar matematika. Hal ini dibuktikan terjadinya peningkatan rata-rata dan ketuntasan hasil belajar siswa. Rata-rata hasil belajar pra siklus sebesar 57,22 meningkat menjadi 78,61 pada siklus I. Kemudian pada siklus II rata-rata hasil belajar menjadi 86,38 . Pada pra siklus persentase ketuntasan klasikal adalah sebesar $44,4 \%$ yaitu pada kategori rendah, pada siklus I meningkat menjadi $80,6 \%$ pada kategori sedang dan pada siklus II meningkat menjadi $91,7 \%$ pada kategori tinggi. Dengan demikian penelitian ini dikatakan berhasil karena telah mencapai 
indikator kinerja yaitu lebih dari sama dengan $85 \%$ atau pada kategori tinggi. Hasil belajar matematika yang meningkat dari pra siklus, siklus I maupun siklus II dikarenakan guru menggunakan model pembelajaran yang menyenangkan yaitu Discovery Learning bermediakan benda konkret. Model Discovery Learning yang menekankan pada proses berpikir secara kritis dan analisis sehingga siswa dapat merumuskan penemuannya sendiri dan memecahkan masalah yang diberikan dengan penuh percaya diri serta media benda konkret membantu siswa dalam memahami pembelajaran dalam permainan, kerjasama dan membantu teman yang belum paham dalam memahami konsep dasar materi yang diajarkan

\section{Daftar Pustaka}

Aisyah, N., dkk. 2007. Pengembangan Pembelajaran Matematika SD. Jakarta: Direktorat Jenderal Pendidikan Tinggi Departemen Nasional.

Arikunto, S. (2007). Penelitian Tindakan Kelas. Jakarta: Rineka Cipta.

Fathani, A.H. 2009. Matematika Hakikat \& Logika. Yogyakarta: Ar-Ruzz Media

Mulyasa, H.E. (2013). Pengembangan dan Implementasi Kurikulum 2013. Bandung: PT Remaja Rosdakarya.

Pardjono, dkk. 2017. Panduan Penelitian Tindakan Kelas. Yogyakarta: Lembaga Penelitian Universitas Negeri Yogyakarta

Sanjaya, W. (2010). Penilitian Tindakan Kelas. Jakarta: Kencana Prenada Media Group.

Suherman, E. (2001). Strategi Pembelajaran Matematika Kontemporer. Bandung: JICA. 